\title{
APPROACHES TO THE STUDY OF INTERNATIONAL MIGRATION: A REVIEW
}

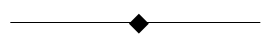

\begin{abstract}
A B STR A C T
This review essay addresses research questions, hypotheses, assumptions, contributions, and shortcomings of predominant approaches to the study of international migration. The discussion concludes with some reflections on future research, particularly on the need to integrate different perspectives.
\end{abstract}

\section{RESU MEN}

La presente revisión aborda cuestiones de investigación, hipótesis, supuestos, contribuciones, y deficiencias de los enfoques predominantes hacia el estudio dela migración internacional. La discusión concluye con al gunas reflexiones respecto a investigaciones futuras, sobretodo en cuanto a la necesidad deintegrar perspectivas disímiles.

\section{INTRODUCTION}

Research on international migration has developed a wide spectrum of theoretical approaches in order to explain theorigins, patterns, and characteristics of migratory flows. Theanalysis in this paper is guided by the discussion of themost conventional and influential approaches

\footnotetext{
* Researcher of facultad de economía. Universidad autónoma de baja california. tijuana, B.C. Member of SNI. E-mail fcuamea@csiatl.tij.uabc.mx
} 
to migration. First, the "push-pull" theory of migration which focuses on macroeconomic conditions in both sending and receiving nations as the key factors that cause migration flows. Second, the "Iabor recruitment" approach, which emphasizes the role of employers in receiving countries as the main "pulling" force that influences the emergence of migration streams. Finally, I shall address theperspective that sees migration as a social process which encompasses economic, social, and cultural variables as explanations of international migration. The discussion underscores the fundamental hypotheses, principles, and shortcomings of each theoretical perspective, suggesting some al ternatives to address further studies of international migration.

\section{THE “OPUSH-PULL” THEORY OF MIGRATION}

Ravenstein's seminal work in thelatenineteenth-century The Laws of Migration, provided the first systematic principles that explain the dynamics of migration (Ravenstein, 1885:167-227). His work was based on five general propositions; the first one is the existing relationship between migration and distance. He differentiates between the short and long distancemigrants, with malepredominancein long-distance migration and female predominance in short-distance movements. Second, Ravenstein identifies a process of stage migration: migrants, he observes, will come first from nearby villages toward the center of attraction or urban area, but as industry and commerce continue to grow, migrants will be attracted from very distant villages as well. Third, henotes rural-urban differences in the propensity to emigrate, whereby theurban population displays a lesser propensity to emigrate than the rural populations. Fourth, developments in technology and modes of transportation, Ravenstein argues, lead to an increase in migration. Last but no least, the rationale behind themigration process, Ravenstein claims, is an individual rational decision, based on calculations of costs and benefits of migration. Economic factors, to sum it up, in the place of origin operateas what Ravenstein defines as "push" forces which, in combination with what hecalls "pull" factors in the destination, explain migration flows. 
The principles and hypotheses of Ravenstein's study became the keystone for further research on migration, leading to what is known as the "push-pull " theory of migration, which has had a great influence on later developments of theoretical models. Although from different ideological and theoretical frameworks, approachessuch as TheTheory of Modernization and The Dependency Theory converge in their assumptions regarding migration as a result of push and pull factors.

Thebasic contention of thesupply-push and demand-pull theory is that the origins of international migration are to be found in the economic backwardness of developing countries, where economic conditions operate as "push" or expulsion forces, fostering legal and illegal migration toward industrialized nations. The "pull" or attraction factors in receiving countries (higher wages, employment, better welfare systems), as well as "push" factors (lower wages, high unemployment and underemployment rates, slow economic growth or economic stagnation and poverty), are considered causal variables that explain how and why international migration flows originate. Although different applications of these assumptions lead to an emphasis on either attraction or expulsion factors, the conventional tenets of this approach assert that the origins, magnitude, and pace of both legal and undocumented migration can be explained as a function of economic performance of receiving and sending nations (A ppleyard, 1989:486-499).

\section{WAGE AND INCOME DIFFERENTIALS}

One of thecentral propositions in theeconomicmodel sof migration is that wage and income differentials between sending and receiving nations account for labor geographical mobility, and that these differentials may be useful to predict the direction of international migration. The hypothesis implies that countries with the lowest per capita incomewould providethehighest differentials compared to the incomein receiving nations. H owever, themain sending countries are not among the poorest nations in the world-rather, many of these countries are "middleincome" nations where "poverty-related 'push" 
factors are probably related more to the distribution than to the level of income" (Morrison, 1982:8). As Gregory argues, in the late 1970's there as a huge flow of illegal Colombian migrants into neighboring Venezuela, and these countries had at the time an income differential of 3.1 to 1 in favor of Venezuela. For that sameyear, incomedifferential between the United States and Colombiawas 10.5 to 1 and no significant Colombian migration towards theUnited States took placeduring those years. Instead of migrating $\mathrm{N}$ orth, wherethewidest incomedifferential could provide stronger attraction, Colombian workers went toward Venezuela, which had a smaller income differential as compared to the U.S. (Gregory, 1991:52). These cases show that wage and income differentials al one providelittleevidenceto sustain the hypothesis that wage and incomedifferentials between sending and receiving nations sufficeto explain migration. In the same line of argument then, Portes argues that the main migration streams toward the United States or Western Europe should originate in the impoverished countries of Equatorial Africa, Bangladesh, or from Haiti, which in fact is not the case (Portes, 1983:76).

For example, in the early sixties after a bilateral labor agreement between Turkey and West Germany was signed, Turkish workers emigrated to West Germany in significant numbers, and the majority were recruited from the regions of Thrace, Marmara, and N orth Central Anatolia, which were considered as the more developed and westernized regions in the country. Gurak and Caces observe that by 1974 emigrants were relatively highly-skilled workers as compared with non-emigrating workers (Gurak and Caces, 1992:150-176). Migrants werenot necessarily the poorest workers in Turkey, nor did they come from the poorest regions of the country as the push-pull theory would claim.

Additional evidence from Latin America conflicts with theoretical assumptions on poverty as related to migration: estimates of poverty in Latin A merica in 1970 show that 68 percent of rural households in Peru were below the poverty line, 75 percent in Honduras, 73 percent in Brazil, 54 percent in Colombia, and 49percent in M exico. Even worse, estimates for that sameyear report that 25 percent of total households 
in Peru were below the destitution line, 45 percent in Honduras, 25 percent in Brazil, 18percent in Colombia, and 12 percent in M exico. By 1980, more than 85 percent of rural households in Bolivia were below thepoverty line, 70 percent in Brazil, 60 percent in Colombia, Honduras, and Venezuela, and 50 percent in Chile, Jamaica, and Panamá. With the exception of M exico, none of these countries experienced massive labor emigration towards the United States in the past twenty years, which apparently does not support the view of migration as a direct result of poverty (Grindle, 1986:113).

At the regional level, there is evidence that contradicts the assumption of direct association between poverty and emigration towards countries with higher wages and income. For instance, in the case of Mexico, if one is to follow thetheory, themain flows of M exican immigrants to the United States should originate from the states of Oaxaca, Chiapas, Hidalgo, and Puebla, which historically has not been the case. (Hernández-Laos, 1984:155-192; Osuna Castelán, 1990: 5-35; Murphy and Stepick, 1984). The southern states of Oaxaca and Chiapas have been thetwo most deprived regions in the history of M exico, and until themid-1960s therewasno significantU.S.-bound migration from Oaxaca or Chiapas. Since the late sixties, however, Oaxacans began migrating toward Mexico's northwest and to thesouthwestern United States, particularly to California. As a result, Oaxaca is now seen as a "new" sending area in M exico. As for theneighboring state of Chiapas, in spite of high poverty levels, low income, and lack of employment (very similar to those in Oaxaca), no significant emigration toward the U.S. has taken place. Furthermore, Butterwoth's case study in Oaxaca shows that internal migration from several rural communities is strongly related with thepeasants' relativelevel of well-being. Hefinds a strong relationship between migration and economic resources available in households; different levels of resources result in distinct patterns of migration: the wealthier, better educated, and Spanishspeaking peasants tend to emigrate more than the poorer, illiterate peasants (Butterwoth, 1975 and 1977:129-139).

If wage and income differentials are deemed as relevant theoretical concepts to explain migration, then they seem to fail to provide 
arguments as to why, inspite of such huge differentials, the number of migrants is not larger or smaller at any particular time, even as differentials widen.

\section{THE ROLE OF UNEMPLOYMENT IN SENDING COUNTRIES}

A nother set of studies in the push-pull tradition focuses on unemployment and underemployment in sending and receiving nations. Gregory argues that unemployment is usually related to high rates of population growth in developing nations, and it is hypothesized that it leads to an expansion of the labor force growing at a higher rate than employment (Gregory, 1991:53). This expanding labor force depresses wages and fosters open underemployment, which in turn pushes many workers to low-wageoccupations in the secondary labor market. Thus, unemployment and underemployment increasethewage differential, and according to the theory, they increase the propensity to emigrate either legally or illegaly. ${ }^{1}$

Thereis no clear evidence, however, that unemployment is directly and significantly related to emigration. For one thing, empirical evidenceshows that unemployment is low among groups of migrants. Mostillegal and legal migrants havea job in their homecountry before leaving, while legal migrants tend to migrateonce they havesecured a job. Migrant workers tend to be employed beforemigrating, and this

\footnotetext{
${ }^{1}$ In the case of rural-urban migration in developing countries, basically internal migration is explained by the impact of employment-unemployment ratios. For a more elaborated model, see John R. Harris and Michael P. Todaro ( 1970:126-142). In his previous work Todaro explained rural migration from a microeconomic decision model, in which a migrant will move to the city even if he does not find a job. The driving forcein the explanation is the migrant's expected wagein the city which has to beexpected largeenough to decideto move is based on availability of accurate information about wages and jobs in destination areas. See Michael P. Todaro (1969:1138-148).
} 
seems to beso in the cases of Turks in Germany, Mexicans in the United States, and Bolivians in Argentina. As Bustamante, Zazueta and García y Griego, and CONEPO show, the high rate of employment among migrants beforethey leave, leads to theargument that unemployment in the sending areas alone is not directly related to emigration propensity (Bustamante, 1979:142; Zazueta and Garcíay Griego, 1982; Penninx, 1982: 781-815; Consejo Nacional dePoblación, 1986). Despite hugenumbers of unemployed workersin sending countries, emigration in most cases comes from specific socio-economic groups. In addition, only a limited number of people leave, and those who leave are not necessarily an accurate representation of the unemployed population nor of every region with high unemployment rates.

A nother theoretical shortcoming in the approach is the failure to explain why the excess labor supply in home countries does not automatically lead to massive migration streams from all over the country. Theemployment/ unemployment ratio does not explain why the size or magnitude of migration flows from sending nations is not correlated with labor surplus and the high unemployment rate.

Jenkins tests the hypothesis in an examination of economic opportunities in U.S. agriculture, measured by wages and levels of farm employment as pull factors for both legal and illegal immigration from Mexico for the period 1948-1972, and by wages and levels of employment in Mexican agricultureas push factors. The results show that agricultural wages and thelevel of farm employment in the U.S. alonewerenegatively related to legal and illegal immigration. Instead, capital investment and agricultural productivity had a relatively powerful pull effect on M exican immigration (Jenkins, 1977:178-189). Jenkins' study suggests that M exican peasants might have responded more to push factors in M exican agriculture than to weak pull factors found in U.S. agriculture during the period studied. Nevertheless, though the study reports statistical relationships, little is said beyond this description about how push factors operate on prospective migrants, or other specific economic forces enhancing migration.

From the pull side, people immigrate even when the receiving country experiences serious economic crisis such as economic recession 
and high unemployment rates. Economic recession and high unemployment rates in the U nited States during the 1980s did not deter inflows of labor migrants, nor did theoil crisis and economic recession in the early 1970s in Western European countries lead to a decrease of legal/ illegal immigration. If the existence of employment in receiving countries aloneis in fact an attraction factor pulling migrants, economic recession and rampant unemployment in destination areas should translate into a reduction of immigration flows by decreasing the economic appeal in destination areas. Fluctuations in the level of employment and economic cycles in receiving countries should reflect quitesimilar patterns in migration inflows.

\section{ECONOMIC GROWTH AND MIGRATION IN SENDING COUNTRIES}

A nother major factor in explaining migration in the same pull-push perspective from a macroeconomic stand point is thelack of economic growth in sending countries. An economy growing modestly or not growing at all can not provide enough employment opportunities for a fast growing labor force. Hence, it is very difficult to providefor better living standards.

Nevertheless, migration also takes place during periods of rapid economic growth and rising income in developing countries. One reason for this is that economic growth is an uneven process which does not take place homogeneously, neither in time nor in space. A common feature of economic growth is that it is shaped by the concentration of capital and investments in particular regions or cities, and/ or in specificeconomic sectors or activities, as was noted by Jenkins (Harvey, 1985; A ydalot, 1980; Lipietz, 1977; Trotsky, 1983). Whilesome regions may experience an economic "boom" or a significant growth rate, the rest of the country may well be economically depressed or growing at a slower pace.

The expectations of better opportunities in a growing region is the driving force that lead people to migrate internally from poor or depressed areas to another region within the country or elsewhere. The evidence shows that economic growth can also foster labor 
emigration. The case of Southeast Asia shows that significant emigration takes place despite economic growth, which is evident in the cases of Asia's four tigers -Singapore, Hong Kong, Taiwan, and South Korea (Sassen-Koob, 1988: chapter four). The case of M exico also seems to support this claim. For example, Mexico's Gross Domestic Product had been growing consistently by about 5 percent annually for almost fifty years from the early 1930s to the early 1980s. Furthermore, during theearly 1970s, theGross National Product ranged between 4.2 and 7.5 percent and it did not stop or reduce both legal and illegal immigration to theU.S. Rather, the number of immigrants increased during that decade. Moreover, between 1960 and 1980, the per capita income in M exico grew at an average rate of 3.7 percent as compared to 2.2 percent in the United State (Sassen-Koob, 1990:373-374).

Several arguments may explain this situation. First, that not all the labor force will have an equal employment opportunity and get an incomethat enables workers to meet their basic needs. The benefits of economic growth are not equally distributed across social groups, nor across all regions in the same country. In fact, one of the most serious challengesfor developing nations isthepromotion of economic growth, creation of well-paid jobs, as well as distribution of income, especially in impoverished areas.

Second, particularly countries with export-oriented manufacturing industries havecreated employment opportunities for young women, attracting rural and urban female workers. Thisal ready predominantly femal emanufacturing sector has changed thecomposition of thelabor market by introducing this "new" labor force. Saskia Sassen-Koob shows that in the Caribbean, Mexico, and Asia, male workers have found themselves "displaced" from manufacturing jobs by young women, at least during the first stages of this export-led manufacturing growth (Sassen-Koob, 1988: 107-110). In turn, an increase of an urban labor-pool tends to depress wages, leading the displaced males to contemplateinternational migration as an alternative.

Therefore, one may conclude that economic growth may lead to the same outcomes described earlier with regard to wages and 
unemployment and their relationship to emigration. Wagedifferentials and high unemployment rates in sending nations, as well asmigration, arealso a consequence of economic growth, rather than a unique result of economic failure or backwardness.

\section{AGRICULTURE AND MIGRATION}

Internal and international migration in Latin A merica as a consequence of economic backwardness in agriculture, havereceived much attention, and in most analysis impoverished peasants are the major source of emigration. Singer contends that rural-urban migration stems from two types of push factors operating in agriculture: factors of change and factors of stagnation (Singer, 1970: 34).

Factors of change are the disruptive effects resulting from the penetration of capitalist production relations in rural areas. Thesefactors lead to the transformation of traditional and subsistence agriculture into a capitalist-oriented production (Singer, 1970: 35) The concentration of productive land in a small number of producers and the introduction of new technologies and mechanization transform the agricultural sector into aless labor-intensiveactivity, "freeing" thelabor force. In Chile, for example, it was estimated that in the early 1970s each tractor replaced about three workers. Furthermore, in Colombia and Venezuela, four workers were similarly replaced; by 1982 it was estimated that in the region of Tucumán, Argentina, 130 harvesting machines replaced approximately 7,800 harvesting workers, a pattern that took placeall over Latin A merica, particularly sincethe 1960s when theGreen Revolution cameinto being (Grindle, 1986:93; Beneciay Forni, 1986:60). ${ }^{2}$ Consequently, peasants face diminishing employment

\footnotetext{
${ }^{2}$ It should be noted that in some cases mechanization resulted in the expansion of agricultural frontier and the potential creation of increases in rural employment, but mostly on temporary basis, which did not alleviate rural unemployment in the longrun.
} 
opportunities, finding themselves landless and without the previous advantage of subsistence production.

Stagnation factors, on the other hand, consist in demographic pressure over land, which becomes more limited either because there is "insufficient" productive land to meet peasants' needs or because thereis an increasein concentration of land holdings (Singer, 1970: 36).

Theories that focus on change and stagnation as push factors in rural areas, contend that theseelements lead to emigration of significant number of peasants. However, the relationship between factors of change as a consequence of new capital ist relations of production on the one hand, and emigration on the other is not an automatic causeeffect relation. Labor surplus does not necessarily translate into emigration, and not all landless and/ or unemployed peasants will emigrate. Furthermore, studies on emigration focusing on rural regions tend to overlook the fact that notall population in rural areas is directly related to agricultural production. Empirical evidencefrom Mexico and other Latin A merican countries confirms that this is the case. A study on Panama reports that peasant families engagein thirty-nine different non-agricultural occupations to generate or supplement their income (Grindle, 1986:127). ${ }^{3}$ A nother study on 28 rural communities in the western state of Jal isco, M exico, a traditional area of emigration to the United States, informs us that 71 percent of those who emigrated to Zamora in Michoacan had non-agricultural occupations in their towns of origin, and that themajority maintained the sameoccupation in the city (Winnie Jr. ,1984). The Balán, Browning, and Jelin study in Monterrey also finds evidence supporting the assertion that not all migrants coming from rural areas have been employed in agriculture (Balán, Browning and Jelin, 1978).

\footnotetext{
${ }^{3}$ However, this does not imply that by diversifying occupations households may actually meet their needs. It just shows that other strategies may take place as survival alternatives.
} 
Families can engage in different and complementary economic activities which may or may not provide sufficient resources to meet their needs as an alternative to emigration. In many cases, migration may bethe last al ternative when all other alternatives havefailed, but it can also be only one among several other survival strategies which may take place at different periods of time, depending on the family lifecycle. ${ }^{4}$

Empirical evidence shows that wage differentials or economic backwardness, and unemployment or lack of economic growth as analytical categories are poor predictors of international migration. Massive migration to Western Europe and toward the United States demonstrates that migrants do not necessarily come from the poorest countries of the world, and that economic differentials per se are not sufficient to account for the origins of migration flows. As Massey, Alarcón, Durand, and González contend, neither pull nor push conditions alonearesufficient to set migration flows in motion; rather, the particular interaction between the two, under particular circumstances and during a given historical moment, is what might result in migration (Massey, Alarcón, Durand, and González, 1987:4).

The overestimation of existing economic differentials has left unanswered questions, such as why countries with thelowest per capita income, and thereforethehighest incomedifferentials, as well as with high unemployment rates and large labor surplus are not among the

\footnotetext{
${ }^{4}$ Thereis a dynamic relationship between the household survival strategies, its life cycle and change in the economic and social environment. Focusing on the household or theexternal conditions al oneas separate units of analysis will certainly obscure the understanding of migration. When the explanation of migration rests on households it tends to overlook theinfluence of contextual factors, and by looking at the latter, the behavior of migrants is viewed as overdetermined by macrostructural conditions. For a view on role of households as a social group and its survival strategies see Charles H. Wood (1981:338-342).
} 
main migrant-sender countries. It has also failed to explain why particular emigration flowsstarted to develop when they did, not before or after, even though economic gaps among countries existed. Other critical issues that this approach fails to answer are: Why is it that only a limited number of individual emigrates, despite the fact that thousands more in the same region or country find themselves in a similar economic situation? Why is not the size of emigration flows larger then it actually is? What accounts for the differences in behavior between those willing to emigrate and those who stay? Why do emigration flows originate from well-identified areas (and not from others under similar or worse circumstances), and why is their destination clearly defined in many cases?

A nother criticism of this theory is that themodels and variables are defined post factum, that is, explaining migration after they have occurred, therefore showing little ability in predicting further flows (Portes and Rumbaut, 1990:223-225; A rizpe, 1978; Boyd, 1989: 638-669; Bach and Schraml, 1982: 320-340). Furthermore, the focus is on macroeconomic causes of emigration, and individuals areanalyzed as mere objects of study whose behavior follows forces beyond their control. Individuals are conceived of as if they have no ability to influence and change their social and economic environment. From this perspective, migration flows will be determined by contextual and structural factors beyond theindividuals capacity to shapetheir destiny. In the view of microeconomic models of migration in the push-pull tradition, migrants behave as individuals who in theory can perceive clearly and esstimate accurately the costs and benefits involved in the prospect of emigrating. Calculations of costs and benefits lead individuals to decide whether to emigrate or not, and it leads them to respond in an adaptivemodeto changes determined by macro-structural factors. These microeconomic models assume that each prospective migrant estimates a subjective function of costs and benefits, constrained only by thelevel of information aboutmigration costs. Thus, individual decision-making constitutes the basic unit of analysis and the main source of explanation of migratory streams, isolating individuals from other social forces that might influence their decisions. 


\section{THE LABOR-RECRUITMENT APPROACH}

Given thelimitations of the push-pull or economic-gaps approach, M.J. Piore has presented an alternative framework concerning the origins of migration flows. His central contention is that labor recruitment is the pivotal strategic factor initiating migration streams, mainly as a response to labor shortages in developed nations and in the oilexporting countries. Instead of focusing on income and wage gaps, Piore's approach deliberately excludes them from the analysis, and looks at employers' recruitment patterns as the central piece of explanation. Sinceforeign labor recruitment patterns have been initiated by employers, what needs to be addressed is the role of employers in receiving countries be it Government's or other official authorities, acting by means of bilateral or unilateral initiatives; employers, acting directly without governmental auspices; or both employers and government agents acting together. Piore writes that:

These recruitment activities seem to explain both the timing of particular migration movements and the particular areas between which migrant flows develop. Recruitment is the key to the seeming paradoxes of migration processes; it explains why one region develops significant out-migration, and another essentially comparable in terms of income, transportation costs, culture, and labor force, never does so... (Piore, 1979: 24. Emphasis added).

Empirical evidence from Western Europe seems to support Piore's claims on the key role of employers' foreign labor force recruitment during the twentieth century, and particularly after theWorld War II.

\footnotetext{
${ }^{5}$ Forced labour recruitment is not part of this analysis, basically because in such cases theexistence of economic and social differences play no activeroleas economic "incentives" for recruited workers. Since most "push-pull" analyses rest on their
} 
European countries experienced labor shortages as a result of a combination of factors, such as a European-wide economic boom in the late 1950s and early 1960s, a low fertility rate during the 1930s, and a high mortal ity rate during the Second World War. In the 1960s, Western Europeimported over 12 million migrants from N orth A frica, Yugoslavia, Greece, Southern Italy, and Turkey as an alternative to cope with labor shortages (Miller and Martin, 1982). Most of foreign labor recruitment in the postwar period took place through bilateral labor treaties between sending and receiving nations.

One example of these agreements is the case of Turkish labor emigration to the Federal Republic of Germany (hereafter referred to only as Germany). Turkish emigration to Germany was formally initiated when the two countries signed a bilateral treaty in October 1961, which allowed Turkish workers to be employed in Germany on the basis of a guest-worker program. Recruited workers weregranted a one-year work permit for a specific job in a particular firm, and they were expected to return home one their contracts had expired. There was no previous migratory experience of Turkish workers in Germany until this binational labor accord was put into practice. (Miller, 1981:9).

The German-Turkish binational agreement was only one among many bilateral agreements that were signed further agreements with Greece, Spain, Turkey, M orocco, Portugal, and Tunisia between 1960 and 1965 al one, and in 1968 signed an agreement with Yugoslavia. In 1948Switzerland signed similar agreements with Italy, and with Spain in 1964 while renegotiating its 1948 treaty with Italy. France signed agreements with Spain in 1961; Morocco and Tunisia in 1963; Turkey

assumptions on economic differentials as motivation to migrate, forced labour does not fit the framework. Workers from colonized countries were either forced to move to certain areas of their own country where labor was needed by colonizers, or they were taken overseas as source of cheap labor. Given that workers migrated against their will, the analysis of economic incentives to migrate in these cases is pointless. SeeA bebe Zegeye and Shubi Ishemo, ed. (1989). 
in 1965; and Portugal in 1971 (Miller, 1981:9). It should bepointed out, however, that of all these governments-sponsored labor agreements, only the Turkish agreement gave rise to new migration flows. In most cases, foreign labor recruitment based on bilateral agreements enhanced and helped to maintain existing international migration flows, rather than originating new ones, i.e. Italian migrants in France.

The case of A Igerian labor migration to Francegoes back to the preFirst World War when mainland employers recruited Algerian labor, particularly Muslim workers from the region of Kabylia. During the First World War, France continued to recruitA Igerian workers in order to replaceFrench workers who had been drafted into thearmy (Garson, 1992:81-83). This first Algerian migration, unlike many other contemporary migration flows towards France, was induced by the employers' direct recruitment without theexistence of labor agreements given that during that period Al geria was considered as part of France.

Other studies from non-European nationsal so provideevidencethat someinternational migration streams areoriginated by theemployers' direct recruitment in out-migration countries, as in the comparative study on migration from two neighboring villages in North-East Thailand. One village (Chiang Wae) had the highest emigration rate whiletheother (Ban Siap) had very low migration experience; although both villages have depended on agriculture and both towns are selfsufficient in agriculture production, only the former had developed emigration flows towards other regions in thecountry and to theM iddle East (Singhanetra-Renard, 1992:191-192). One of the main factors accounting for such different emigration patterns in spite of social and economical similarities, stems from thefact that villagers from Chiang Wae were initially recruited by aU.S. construction company building military facilities in the country, while no recruiting took placein Ban Siap. Massive emigration of Thai workers to theMiddle-East countries began in the mid-seventies, when United States and other foreign construction companies located in Thailand moved to the Gulf States once the U.S.A. military presenceended in Thailand. Companies that were granted building contracts in the Middle East relocated their operations there. 
Employers often recruited foreign labor based on ethnicity as the selection criteria. Thailand and many other Asian countries were targeted by the Gulf Nations as an alternative to Arab workers, particularly Palestinians, Iranians, and Iraqis, who have been traditionally seen as a serious threat to the political stability of host nations. ${ }^{6}$

Construction companies that had formerly worked in Thailand turned to their former Thai employees as a source of labor. In themid1970s Thai international migration was virtual ly non-existent; in 1976, the first Thai worker was recruited by a U.S. company to work in Bahrain and then in Saudi Arabia. By 1986, Thai migrants werefound in 26 countries as a consequence of increased recruitment of Thai workers to go overseas (Singhanetra-Renard, 1992:193). In 1981, the number of Thai Workers in the Middle East was about 159,000 and it increased to about 230,000 in 1986; 80 percent of them wereemployed in Saudi Arabia at the time.

International recruitment agents and Thai government's own agencies soured sincethelate 1970, thereby competing with each other to control the demand of foreign labor in MiddleEast and other A sian countries. Meanwhile, no international migration having originated from Ban Siap had been reported. Unlikevillagersfrom Ban Siap, people from Chiang Wae had the opportunity to make contact with other regional migration streams in Thailand and with foreign companies, which in turn gave them the links and information about the possibilities of working abroad.

In sum, under conditions of labor shortages, nations commonly face the following options to cope with it: they can substitute capital for labor; they can adjust the product mix, thus, employers would

\footnotetext{
${ }^{6}$ The change in the demographic composition and origin of labour migrants in the Persian Gulf States as a result of political and ideological cleavages are discussed in Myron Weiner ( 1982:1-36); Sharon Stanton Russell (1989:24-47).
} 
concentrate on products that lend themselves best to automated production and stop producing thosethat do not; they can rely on other sources of labor, such as retired persons, married women, or nonworking women; they can subcontract a part of their operations within their country or overseas, and finally, their employers can relocatetheir firms abroad.

These possibilities exist as alternatives to foreign labor, and they imply that coping with labor shortages by means of foreign labor recruitment may be useful in some cases. Empirical evidence helps to better illustratethepoint. TheSwiss case in the 1940s is a clear example of how employers adjust to labor shortages under governmental restricted access to foreign labor. Since 1973-1974, Swiss authorities have permitted only a limited number of foreign workers to enter the country regardless of what employers' needs for labor might have been. Current conditions are not as flexible as they were in the 1940s. The current policy has influenced employers in very different ways. Employers havegonethrough several adjustment strategies given that they cannot rely so freely on foreign labor. A study carried out during the 1970s shows that 42 percent of the industries surveyed $(n=250)$ had adjusted by substituting capital for labor as a response to labor shortages; 26 percent opted for investing abroad; 14 percent decided subcontracting abroad; and 10 percent subcontracted with other Swiss companies (Maillat, Jeanrenaud and Widmer, 1978: 733-736).

In the 1950s and the 1960s Japan also experienced labor shortages comparableto those in Western Europe, but sincethe Japanese rejected the alternative of importing Korean workers as they did in the 1930s, the result was that many labor-intensive Japanese industries moved to Korea (Weiner, 1990:142).

Thelabor recruitment approach tends to overemphasizeemployers' needs as the driving "pull" force originating migration flows, while conditions in migrant-sending countries constitute a passive factor. Labor recruitment as an explanation of the origins of migration represents a theoretical improvement over the push-supply and pulldemand framework, sinceit provides a specific historic mechanism to explain migration flows. It also explains differences in migration 
patternsamong countries and regions with similar push and pull forces acting on them, and it also points at the origin of the flows. ${ }^{7}$

\section{MIGRATION ASSOCIAL PROCESS}

The problem with conventional approaches to international migration, according to Portes' argument, is that "...these descriptions of the origins of immigration are not necessarily inaccurate, nor entirely useless", but "are... theoretically incomplete..." (Portes, 1983:72). One could add herethat their limitations call for a far more comprehensive and elaborated theory of international migration.

Recent research in the field attempts to integrate a variety of approaches into a single framework that is informed by traditional perspectives, i.e. push-pull theory, labor recruitment, historicalstructural approaches, as well as developments on the perspective of the global economy, social and migration networks, and linkages between sending and receiving nations. The emerging approach of international migration is guided by theconcept of Migration Systems, which focuses its attention to both ends of migration flows (Kritz and Zlotnik, 1992, in Kritz et. al. 1992:1-3).

This view holds that sending and receiving areas should beanalyzed as two components of the migration system, and which interrelated by a complex set of linkages: stateto staterelations (tradeand financial flows, immigration and emigration policies, complementary of labor supply and demand; family and personal networks (remittanceflows, family obligations, community solidarity, information); migrant agency activities (job recruitment, regulations governing themigration process, contracts with migrant workers); and mass culture connections (international media dissemination, societal acceptance of migrants,

${ }^{7}$ The role of labor recruitment as explanation of the origins of migration has been subjected to severescrutiny. H owever, critics of Piore's proposal very often overlook thelimitations pointed out by Piorehimself. Seefor instance thecritiqueby Portes (1983:73). 
cultural similarity, assimilation) (Fawcett, 1989:673-675; Fawcett and Arnold, 1987:457).

This emerging approach sees migration primarily as a social process rather than a process that results from isolated individual actions. The explanations of migration flows focus on individuals as member of a larger social structure, i.e. family and households, which are influenced by macroeconomic factors. Faw cett and Arnold arguethat the focus on migration as a social process attempts to avoid the previous theoretical fragmentation of the study of migration, where individual behavior was perceived as atomistic. (Fawcett and A rnold, 1987:455-456).

This approach conceives migration as a dynamic process that takes place over time, within which distinct intervening variables may play a role in its different stages, which in turn may influence the flows by shifts in thedirection, thesize, composition, and volume of migration. Further, thehistorical perspective on migration flows in this framework allows for the identification of interactions between migration flows and structural conditions in both sending and receiving countries affecting migration.

One of thecentral propositions of themigration system approach is that international migration originates in structural transformations taking placein sending and recei ving countries. (Massey, etal., 1987:5). Economic and social differences at both ends of themigration flow are necessary conditions for the existence of labor migration across international borders. It is necessary that workers arewilling and able to emigrate, and that employers and countries are willing to accept them at least on a temporary basis-as legal or undocumented migrantsand of course, it is important that wage and income gaps exist.

However, theseconditionsalonearenot ableto explain international migration. Whileprevious approaches relied basically on theeconomic necessary preconditions as causes of migration, they failed to provide an accurateanswer; this dueto thefact that, although those conditions are necessary, they are not sufficient to explain migration movements (Böhning, 1984:35). Therefore, economic factors condition the flows, but are not the causes of labor migration. 
The analysis of migration as a social process is guided by variables such as the dynamics of emerging and maturemigration networks, and thesocial and cultural ties between sending and receiving communities, which in turn creates "daughter" communities in the receiving country. Migration networks develop social institutions among migrants - sociedades mutualistas, recreational clubs, committees that organize religious celebrations in their hometowns- that strengthen social ties between sending and receiving regions, whilesustaining a permanent flow of migration. The perspective of migration as a social process also takes into account the role of individuals in households and families, as well as their relationships with migration networks in thecommunity as a means to understand and explain international migration. The concept of migration networks, and therole of families and households as explanatory variables of migration provide additional insights on how migration flows are sustained across time.

\section{MIGRATION NETWORKS}

Empirical observation on international migration flows demonstrate that oncethemovement of peoplebegins, it developsa social infrastructure that enables further massive migration. (Massey, et al., 1987:5). Migration networks develop social ties linking certain sending communities with particular areas of destination in host societies. They play an important rolein international migration becausethey operate as channels of information and resources, providing short-term assistance, and influencing theselection of destination and origin sites, as well as self-selection of migrants by reducing migration costs and risks.

The most common relationships among migration networks are based on kinship, friendship, and paisanaje. ${ }^{8}$ Migration networks play

${ }^{8}$ These relationships are not strictly pre-determined; their functions may change over time, their relevance is not homogeneous among ethnic groups in different cultural environments, and they can also be influenced by political or economic 
a relevant role in regional and individual selectivity, and in many instances explain why individuals in regions under similar economic and social conditions show different patterns associated to migration. Thecase of Turkish migration to Germany in theprevious section serves to illustratethe point.

Policy factors play a rolein the regional selectivity of migrants from someareas rather than others. Policiesaiming at single-malemigrants, between certain ages, with particular skills or for specific types of jobs -industrial, agricultural, or service may tend to enhance emigration from certain areas. For example, the Turkish government gave priority to groups from theareas characterized as being in need of development, and the government also favored emigration from regions where it had implemented the Village Development Co-operatives Program (Wilpert, in Kritz et. al., 1992:177-189). The government also encouraged emigration to Germany from the flooded and earthquake areas as a means to alleviate an aggravated social need. However, such regional selectivity does not address theissue of who is morelikely to emigrate and who is not, and why.

Distinct migration patterns arealso observed within ethnic groups: while Kurdish people from Yeniköy, for example, did not develop significant migration networks to Germany, theKurdsfrom theEastern province of Erzurum created an extensivemigration network between Erzurumand theGerman city of Baden-Württemberg (Wilpert, in Kritz et. al., 1992:177-189). These dissimilar migration networks show that migration patterns changefrom onevillageto another, from onesocial groups to another, and even within the same ethnic group. Although particular migration networks may take different forms in different

factors. Paisanajerefers to individuals with a common origin, coming from thesame community or village. See Massey, et. al. (1987:140-141), and Harvey M. Choldin, (1973:163-176). 
societies or ethnic groups, it is possible to draw generalizations about the origins and maturation of migration flows, and their role in enhancing or preventing migration.

Social and migration networks determine, to a certain extent what regions or areas are more likely to begin migration flows, what individualsmay beinvolved in theprocess, and also which destinations areas are more likely to receive migrants from certain origins and maintain a permanent flow of migration. In many instances, the network al so determines thetype of job to be occupied by newcomers. In many cases poor occupational position of members of the network is a consequence of the limited resources and relationships of the network. N ew migrants relying on a network of workers employed in marginal jobs may tend to increase concentration of migrants in the same positions, at least whilemigrants adapt to thenew environment, as Gurak and Caces find in the case of Filipino migrants to Hawaii, and in Portes' study of Dominicans in New York (Gurak and Caces, 1992:155; Portes and Sensenbrenner, 1993:1320-1350). However, this need not be necessarily the case of networks with limited resources. Goldring provides evidence that migrants whose first jobs were in a marginal position havemanaged to move out to different occupations, or leave the secondary labor market and move upward. In any event, migration networks have a significant influence in determining the migrants insertion in the labor market, depending on networks' resources, degree of commitment of members involved, and development of the network. ${ }^{9}$

\footnotetext{
${ }^{9}$ Although networks are important, one should not disregard that migrants incorporation into thelabor market is influenced by migrants'skills, whether they speak thelanguageor not, level of education and their legal status. In order to avoid simplistic generalizations, a word of caution should besaid: on theonehand, Portes and Böröcz's position that migrants incorporation is determined to an extent by what they call "contexts of reception", namely a hostile environment of reception will push migrants to work in very a disadvantageous situation, providing little opportunities of occupational mobility. On theother, Goldring's argument is that it
} 


\section{FAMILIESAND HOUSEHOLDS}

As international migration becomes more accessible and as networks perform therole of sustaining theflows, migration will bean alternative that shall increasingly adopted by families and households. The analysis of migration as a social process focuses its attention on the individual -current or potential migrant-as a member of family or a household.

The social process approach views the family as a central unit of analysis, in which individuals play specific roles (Boyd, 1989:642). Studies haveshown that the decision to migrateis not a decision taken by the migrants al one, but is a result of the conditions and structure of the household unit (Pessar, 1982:343-362). As a sustenance unit, households shapemotivations and propensity to emigratedepending on the availability of resources, age, and sex of household members, and the stage of the family life-cycle. Households with few adults are less likely to engage in migration because there might be fewer "candidates" to emigrate. Conversely, households with many dependent children have shown to be less likely to participate in migration when the income-generating capacity is very low for members who would beleft behind (Pessar, 1982:343-362).

The household, defined as a co-resident group which ensures its maintenanceand reproduction by generating and allocating a common pool of resources, organizes different strategies of survival, with migration being one of them.

is not necessarily the case and that Portes and Böröcz conceive migrants as passive agents, without making distinctions among different groups of the samenationality or ethnic origin. While they find evidence on "contexts of receptions" in the case of illegal Jamaican and Dominican doctors and dentists in New York and Turkish translators in Germany, Goldring finds opposing evidence from migrants from several Mexican communities. This shows someconstrains on the role of migration networks, which varies across different groups. (See Portes and Böröcz, 1989:618621; Goldring, 1991). 
Unlikeconventional explanations of migration decision-making, the household is involved as an important factor in deciding whether or not to engage in migration, and in deciding when and who will participate in the process.

The role of households can not be overlooked in the study of international migration because, as Boyd argues, "household survival mechanismsal so show why migration does not al ways occur..." (Pessar, 1982:365) and that different survival strategies take place over time. For instance, predominant male migration from several communities in Western Mexico illustrates how migration is a changing al ternative at different stages of the family life-cycle. Massey et. al. have found that

Active migration begins at a high level among young unmarried men, falls after marriage, rises with the arrival of children, and then falls again as the children matureand leave home. In short, over the course of a man's life cycle, active migration rises and falls depending on family needs, while the number with migrant experience steadily grows. By the end of their life cycle, most men have been to the United States but are no longer active migrants. (Massey, et al.1987:200)..$^{10}$

In the communities studied by Massey et al., men had the main economic role as provider of resources of the household. When migration appeared as the al ternative to follow, the rest of the family stayed behind under supervision of wives, and relying on thesupport

\footnotetext{
${ }^{10}$ Similar migration strategies during different stages of the family life cycle are reported by Lourdes A rizpein thecaseof internal migration from two communities to Mexico City, in Migración, Etnicismo y Cambio Económico.
} 
of the extended family. ${ }^{11}$ In the Mexican tradition, women play an important role as mothers and their function in the household organization is most of the time related to both biological and social reproduction.

The discussion in this paper makes clear that currently there is no general theory to explain all types of migration movements and their origins, or to explain how they are sustained and how they have envolved. Empirical evidenceshows that wagedifferentials or economic backwardness, and unemployment or lack of economic growth as analytical categories are poor predictors of international migration.

Several approaches have attempted to address specific migration movements in given periods of time but leaveasidedifferent migration flows which apparently respond to peculiar combinations of economic, social, and political circumstances not contemplated by particular frameworks. On one extreme of the theoretical spectrum is the neoclassical economic approach -in which migrants respond to the spatial distribution of production factors moving from areas where capital and economic opportunities are limited to regions with abundant capital, economic growth and employment opportunities- decisions stem from individuals' rational evaluations of costs and benefits of migration. On the opposing end are the frameworks based on assumptions of economic differentials as the sufficient driving force causing migration streams, as well as approaches focusing on sociological variables without including economic or political factors. Asit has been recognized by Massey et. al., Fawcett and A rnold, Boyd, Portes, and Kritz, the challenge in the field of international migration

${ }^{11}$ This situation varies across different structures of household units: in Caribbean households, males do not provideenough resources to satisfy survival needs, which resulted in a female-led emigration towards the United States (see Ho, 1993:33-34). For a case of male-led emigration which evolved into a female-led migration, see R.B.M. Korale (1986: 213-234). 
is to devel op further studies and theoretical frameworks with the goal of integrating several approaches into a comprehensive framework, which in turn could providea better way of studying and explaining migratory processes. However, the main implication for immigration policy-making purposes is thefact that very often themain arguments are supported on traditional supply-push and demand-pull factors alone, which in turn are difficult to sustain. The perspectiveto analyze migration as a social process constitutes an inclusiveeffort not to dismiss or neglect traditional and partial views. Rather, itaims at theintegration of different theoretical developments into a global perspective that might lead to a comprehensive explanation and understanding of particular migration processes.

However, neither the push-pull tradition nor thesocial linkages and networks approaches address political factors, such as immigration policies and state to state relations, as intervening variables in the international migration pictures as a whole. They do not analyzehow political variables might shape the patterns, magnitude, and pace of international migration flows-both legal or illegal.

Theanalysis of political variables, -particularly immigration policiesand how they influence international migration are deemed relevant for a better understanding and explanation of this phenomenon. The role of immigration policies in shaping international migration flows, and the mechanisms and strategies that several receiving countries have implemented in order to control immigration flows demand further research. 


\section{REFERENCES}

Appleyard, Reginald T. (1989). "Migration and development: myths and reality", International M igration R eview, 23, fall.

A rizpe, Lourdes (1978). M igración, Etnicismo y Cambio Económico. U n

Estudio de Caso sobre M igrantes Campesinos a la Ciudad de M éxico,

El Colegio de México, México.

Aydalot, Philippe (1980). D inamique Spatiale et D eveloppement Inégal, Paris, Economica.

Bach, Robert L. and Lisa S. Schraml (1982). “Migration, crisis and theoretical conflict", International Migration Review, 16(2), Summer.

Balán, Jorge, Harley H. Browning and Elizabeth Jelin (1978). Men in a Developing Society. Geographic and Social Mobility in Monterrey, México, The Texas University Press, Austin.

Benencia, Roberto y Floreal Forti (1986). “Los procesos de transformación delas migraciones temporarias en el contexto de una provincia productora de mano de obra: Santiago de Estero, Argentina", in Se Fué a Volver. Seminario sobre Migraciones Temporales en América Latina, México, El Colegio de México.

Böhning, W.R. (1984). Studies in International Labour Migration, St. Martin's Press, New York.

Boyd, Mónica (1989). "Family and personal networks in international migration: recent devel opments and new agendas", International M igration Review, 23 (3), Summer.

Bustamante, Jorge A . (1979). “Undocumented Immigration from Mexico: Research Report", International M igration Review, 11(2), Summer.

Butterwoth, Douglas (1977). "Selectivity of Out-M igration froma Mixtec Community", U rban A nthropolgy, 6(2), Summer.

1975. Tilantongo: Comunidad M ixteca en Transición, México, SEPINI, serieno. 38.

Consejo N acional de Población (1986). Encuesta en la frontera nortea trabajadores indocumentad os devueltos por las autoridades de losEstados Unidos deA mérica, México, conAPO. 
Choldin, Harvey M. (1973). "Kinship Networks in the Migration Process", International M igration Review , 7(2), Summer.

Fawcett, James T. (1989). "N etworks, linkages, and migration systems", International M igration Review, 23 (3), Fall.

Fawcett, JamesT. and Fred Arnold (1987). "Explaining Diversity: Asian and Pacific Immigration Systems", in Pacific Bridges. The $\mathrm{N}$ ew Immigration from A sia and the Pacific I slands, James T. Fawcett and Benjamin V. Cariño, ed., N ew York: Center for Migration Studies. Garson, Jean Pierre (1992). "Migration and Interdependence: The Migration System Between France and Africa", in International M igration Systems. A Global A pproach, Mary M. Kritz, Lin Lean Lim and Hania Zlotnik, ed., Clarendon Press, Oxford.

Gregory, Peter (1991). "The Determinants of International Migration and Policy Options for Influencing theSize of Population Flows", in Determinants of Emigration from Mexico, Central America, and the Caribbean, Sergio Diaz-Briquets and Sidney Weintraub, ed., Series on Development and International Migration in Mexico, Central America, and the Caribbean Basin (Boulder: Wesview Press, 1991).

Grindle, MerileeS. (1986). Stateand Countryside. D evelopment Policy and A grarian Politics in Latin A merica (Baltimore: The Johns Hopkins University Press).

Goldring, Luin (1991). "Theoretical Implications of Diversity in the M odes of Incorporation of M exicans in the United States", Paper Presented at the A nnual Meeting of the Latin A merican Studies Association, Washington, D.C.

Gurak, Douglas T. and FeCaces (1992). “Migration Networks and the Shaping of Migration Systems", in Mary M. Kritz, Lin Lean Lim, and Hania Zlotnik, ed., International M igration Systems. A Global A pproach (Oxford:Claredon Press, 1992).

Harris, John R. and Michael P. Todaro (1970). "Migration, unemployment and Development: a Two-Sector Analysis", The A merican Economic Review, 60(1), March.

Harvey, David (1985). TheU rbanization of Capital, Baltimore, The Johns Hopkins University Press. 
Hernández-Laos, Enrique(1984). “La desigual dad regional en México (1900-1980), in Rolando Cordera and Carlos Tello, ed., La D esigualdad en M éxico, México, Siglo XXI.

Ho, Christine G.T. (1993). "Theinternationalization of kinship and the feminization of Caribbean migration: the casse of AfroTrinidadian Immigrants in Los A ngeles", Human Organization, 52(1), Spring.

Jenkins, J. Craig (1977). "Push-Pull in recent M exican migration to the U.S.", International M igration Review, 2, Summer.

Kritz, Mary M. and Hania Zlotnik (1992). "Global Interactions:

Migration Systems, Processes, and Policies", in Kritz, et al. 1992. Korale, R.B.M. (1986). “Migration for Employment in the MiddleEast: Its Demographic and Socioeconomic Effects on Sri Lanka", in A sian Labor M igration. Pipelineto the M iddleEast, Fred Arnold and Nasra M. Shah, ed., Boulder: Westview Press.

Lipietz, Alain (1977). Le Capital et son Escape, Paris, Maspero.

Maillat, D., C. Jeanrenaud and J. Ph. Widmer. 1978. "Reactions of Swiss Employers to thel nmigration Freeze", International Labour R eview, 117(6), November-December.

Massey, Douglas, Rafael Alarcón, Jorge Durand and Humberto González (1987). Return to A ztlan. TheSocial Process of International $M$ igration from Western M exico, University of California Press, Berkeley.

Miller, Mark J. (1981). Foreign Workers in W estern Europe an Emerging Political Force, Praeger Publishers, New York.

Miller, MarkJ. and Philip L. Martin. 1982. A dministering Foreign-W orker Programs, Lexington Books, Lexington.

Morrison, Thomas K. (1982). "The relationship of U.S. aid, trade and investment tomigration pressures in major sending countries", International M igration Review, 26 (1), spring 8.

Murphy, Arthur D. and A lex Stepick (1984). Social I nequality in 0 axaca.

A History of Resistance and Change, Philadelphia: Temple University Press.

OsunaC., Germán (1990). “Dinámicadeladesigualdad regional en México, 1970-1980”, Estudios D emográficos y U rbanos, 5(1), enero-abril. 
Penninx, Rinus (1982). "A critical review of theory and practice: the case of Turkey", International M igration Review, 16(4), Winter.

Pessar, Patricia (1982). "Theroleof householdsin international migration and the case of U.S.-bound migration from the Dominican Republic", International M igration R eview , 16(2), Summer.

Piore, Michael J. (1979). Birds of Passage. M igrant Labor and Industrial Societies, CambridgeUniversity Press, New York.

Portes, A lejandro (1983). “International Labor Migration and N ational

Development", in Mary M. Kritz, ed., U.S. Immigration and R efugee Policy. Global and D omestic Issues, (Lexington: Lexington Books). Portes Alejandro and Jószef Böröcz (1989). “Contemporary Immigration: Theoretical Perspectives on its Modes of Incorporation", International M igration Review, 23(3), Fall.

Portes, A lejandro and Julia Sensenbrenner (1993). “Embeddedness and immigration: notes on the social determinants of economic action", A merican Journal of Sociology, 98(6), May.

Portes A lejandro and Rubén G. Rumbaut (1990). Immigrant America.

A Portrait, University of California Press, Berkeley.

Ravenstein, E.G. (1885). "The Laws of Migration", Journal of the Royal Statistical Society, no. 48.

Sassen-Koob, Saskia (1988). TheM obility of Labor and Capital. A Study in

International Investment and Labor Flow, New York, Cambridge University Press.

(1990). “U.S. Immigration Policy Toward Mexico in a Global Economy", Journal of International Affairs, 43(2), Winter.

Singer, Paul. 1970. Economía Política dela U rbanización, México, siglo XXI. Singhanetra-Renard Anchalee (1992). "The Mobilization of Labour

Migrantsin Thailand: Personal Links and Facilitating Networks", in Mary M. Kritz, et al.

Stanton Russell, Sharon (1989). "Politics and ideology in migration

Policy formation: The Case of Kuwait", International M igration Review, 32(1), Spring.

Todaro, Michael P. (1969).“A model of Labor Migration and Urban Unemployment in Less Developed Countries", The A merican E conomic Review, 59(1), March. 
Trotsky, León (1983). La Ley del D esarrollo D esigual y Combinado, México, Quinto Sol.

Weiner, Myron (1982). "International Migration and Development: Indians in the Persian Gulf", Population and D evelopment R eview, 8(1), March.

— 1990. "Inmigration: perspectives from receiving countries", Third Workd Quarterly, 12(1), January.

Wilpert, Czarina (1992). "The Use of Social Networks in Turkish Migration to Germany", in Kritz, et al. 1992.

Winnie, William W. Jr. (1984). El papel delos centros urbanos medianos y pequeños en la retención migratoria del estado de al asco, Universidad deGuadalajara, Cuadernos deDivulgación, núm 11, Guadalajara. Wood, Charles H. (1981). "Structural changesand household strategies: a conceptual framework for thestudy of rural migration", H uman organization, 40(4), Winter.

Zazueta, Carlos H. and Manuel García y Griego (1982). Los T rabajadores $M$ exicanos en Estados U nidos: R esultados de la Encuesta $\mathrm{N}$ acional de Emigración a laFrontera $\mathrm{N}$ ortedel País y a los Estados U nidos, México, Secretaría del Trabajo y Previsión Social, SerieA nálisis 3.

Zegeye A beb sand Shubi Ishemo, ed. (1989). Forced labor and M igration: Patterns of M ovement Within A frica, Hanz Zell Publishers, London. 